\title{
Towards a neurocognitive model of pain-related fear
}

Citation for published version (APA):

Biggs, E. E. (2021). Towards a neurocognitive model of pain-related fear. [Doctoral Thesis, KULeuven, Maastricht University]. KU Leuven/Universiteit Maastricht. https://doi.org/10.26481/dis.20210312eb

Document status and date:

Published: 12/03/2021

DOI:

10.26481/dis.20210312eb

Document Version:

Publisher's PDF, also known as Version of record

\section{Please check the document version of this publication:}

- A submitted manuscript is the version of the article upon submission and before peer-review. There can be important differences between the submitted version and the official published version of record.

People interested in the research are advised to contact the author for the final version of the publication, or visit the DOI to the publisher's website.

- The final author version and the galley proof are versions of the publication after peer review.

- The final published version features the final layout of the paper including the volume, issue and page numbers.

Link to publication

\footnotetext{
General rights rights.

- You may freely distribute the URL identifying the publication in the public portal. please follow below link for the End User Agreement:

www.umlib.nl/taverne-license

Take down policy

If you believe that this document breaches copyright please contact us at:

repository@maastrichtuniversity.nl

providing details and we will investigate your claim.
}

Copyright and moral rights for the publications made accessible in the public portal are retained by the authors and/or other copyright owners and it is a condition of accessing publications that users recognise and abide by the legal requirements associated with these

- Users may download and print one copy of any publication from the public portal for the purpose of private study or research.

- You may not further distribute the material or use it for any profit-making activity or commercial gain

If the publication is distributed under the terms of Article $25 \mathrm{fa}$ of the Dutch Copyright Act, indicated by the "Taverne" license above, 
Emma Biggs. Towards a neurocognitive model of pain-related fear. Doctoral thesis offered to obtain the degree of Doctor of Psychology (PhD) at KU Leuven and the degree of Doctor at Maastricht University, within the framework of a joint doctorate, 2021.

(Co-)Supervisors: Prof. dr. Johan Vlaeyen (KU Leuven), Prof. dr. Rainer Goebel (Maastricht University), Dr. Ann Meulders (KU Leuven), Dr. Amanda Kaas (Maastricht University)

Contemporary biopsychosocial models of chronic pain, such as the fear-avoidance model (Vlaeyen et al., 2016; Vlaeyen and Linton, 2012, 2000), posit that pain-related fear plays a pivotal role in the development and maintenance of the disability experienced by patients. Yet, as discussed in Chapter 1, our knowledge of the neuro-cognitive mechanisms underlying pain-related fear is limited. This led us to develop an experimental paradigm that mimicked the pain-related fear individuals with chronic pain may experience as a consequence of stimulus-evoked pain (e.g., allodynia; perceiving non-painful touch as painful) or as a consequence of stimulus-independent pain (e.g., spontaneous pain fluctuations). We developed a classical cued and contextual fear conditioning paradigm that employed innocuous vibrotactile stimulation of the fingers as conditioned stimuli (CSs) and painful electrocutaneous stimulation of the ipsilateral wrist as an unconditioned stimulus (US). With this paradigm and meta-analytic methods, we addressed the following research questions: 1) do participants acquire (Chapter 2), generalize (Chapter $\mathbf{3}$ ), and extinguish (Chapter 2) conditioned fear responses to touch when associated with pain? 2) Are the neural correlates of pain-related fear comparable to the neural correlates of other conditioned fears (using merely aversive, non-painful stimuli as USs) (Chapter 4)? 3) What are the neural networks related to fear of touch (Chapter $\mathbf{5}$ )?

We found that participants successfully acquired and extinguished both cued and contextual fear of touch (Chapter 2). However, we did not find evidence of fear generalization to novel touch (Chapter 3). From these results we conclude that pain-related fear responses to innocuous touch can develop and reduce in a manner consistent with contemporary associative learning theories, although the spreading of fear of touch requires further investigation. We found that the neural network relating to the acquisition of cued fear of touch included regions involved in emotional learning processes (putamen, angular gyrus, anterior insula, and ventromedial prefrontal cortex/vmPFC), motor regions (primary motor cortex/MI and supplementary motor area/SMA), and somatosensory regions (primary and secondary somatosensory cortices/SI and SII). The neural correlates of contextual fear of touch were limited to the bilateral caudate nuclei (Chapter 5). These results, combined with our finding that the primary somatosensory cortex (SI) is differentially recruited for pain-related fear compared to other conditioned fears (Chapter 4), points to a crucial role for somatosensory processing in the experience of pain-related fear. In Chapter 6, we discuss the potential implications of these findings, and directions for future research that could build on this work. 
Emma Biggs. Naar een neurocognitief model van pijn-gerelateerde vrees. Proefschrift aangeboden tot het verkrijgen van de academische graad van Doctor in de Psychologie in het kader van een gezamenlijk doctoraat aan de KU Leuven en de Universiteit Maastricht, 2021. (Co-)Promotoren: Prof. dr. Johan Vlaeyen (KU Leuven), Prof. dr. Rainer Goebel (Maastricht University), Dr. Ann Meulders (KU Leuven), Dr. Amanda Kaas (Maastricht University)

Hedendaagse biopsychosociale modellen van chronische pijn, zoals het vreesvermijdingsmodel (Vlaeyen et al., 2016; Vlaeyen and Linton, 2012, 2000), stellen dat pijngerelateerde angst een centrale rol speelt in de ontwikkeling en instandhouding van ervaren beperkingen. Echter, zoals besproken in Hoofdstuk 1, is onze kennis van de neuro-cognitieve mechanismen van pijngerelateerde angst nog steeds zeer beperkt. Dit bracht ons ertoe om een experimenteel paradigma te ontwikkelen dat de pijngerelateerde angst nabootst die patiënten kunnen ervaren als gevolg van pijn die wordt uitgelokt door een stimulus (e.g., allodynie; waarbij een niet-pijnlijke aanraking als pijnlijk wordt ervaren) of als gevolg van pijn die niet samenhangt met een stimulus (e.g., spontane pijnfluctuaties). We ontwikkelden een klassiek gecued en contextueel angstconditioneringsparadigma waarin onschadelijke vibrotactiele stimulatie van de vingers worden ingezet als geconditioneerde stimuli (CSs) en pijnlijke elektrocutane stimulatie van de ipsilaterale pols als een ongeconditioneerde stimulus (US). Met dit paradigma en met meta-analytische methoden hebben we de volgende onderzoeksvragen beantwoord: 1) kunnen deelnemers geconditioneerde angstreacties voor een aanraking die gepaard gaat met pijn ontwikkelen (Hoofdstuk 2), generaliseren (Hoofdstuk 3), en uitdoven (Hoofdstuk 2)? 2) Zijn de neurale correlaten van pijngerelateerde angst vergelijkbaar met die van andere geconditioneerde angsten (waarbij aversieve, nietpijnlijke stimuli als US gebruikt worden) (Hoofdstuk 4)? 3) Wat zijn de neurale netwerken die ten grondslag liggen aan angst voor aanraking (Hoofdstuk 5)?

We toonden aan dat deelnemers angst voor aanraking konden ontwikkelen en uitdoven (Hoofdstuk 2), maar we vonden geen bewijs voor generalisatie van zulke angst naar nieuwe aanrakingen (Hoofdstuk 3). Uit deze resultaten concluderen we dat pijngerelateerde angstreacties voor onschadelijke aanrakingen zich kunnen ontwikkelen en weer uitdoven op een manier die in lijn is met hedendaagse associatieve leertheorieën, maar dat de verspreiding van angst voor aanraking verder onderzoek vereist. Daarnaast vonden we een neuraal netwerk dat betrokken is bij het ontwikkelen van gecuede angst voor aanraking, bestaande uit hersengebieden die betrokken zijn bij emotionele leerprocessen (putamen, gyrus angularis, insula anterior, en de ventromediale prefrontale cortex/vmPFC), motorische gebieden (primaire motorische cortex/MI en supplementaire motorische schors/SMA) en somatosensorische gebieden (primaire en secondaire somatosensorische cortex/SI en SII). De neurale correlaten van contextuele angst voor aanraking waren beperkt tot de bilaterale nuclei caudate (Hoofdstuk 5). Deze resultaten, gecombineerd met onze bevinding dat de primaire somatosensorische cortex (SI) anders wordt ingezet voor pijngerelateerde angst in vergelijking met andere geconditioneerde angsten (Hoofdstuk 4), wijzen op een cruciale rol voor somatosensorische verwerking in de ervaring van pijngerelateerde angst. In Hoofdstuk 6 bespreken we de implicaties van deze bevindingen, en geven we een aantal mogelijke richtingen aan voor toekomstig onderzoek dat zou kunnen voortbouwen op dit werk. 